Review

\title{
Mindfulness in Tai Chi Chuan as Practised amongst Higher Education Students with Implications for Health and Learning: A Narrative Review
}

Marcus A. Henning ${ }^{1,}{ }^{*}$, Xuan Joanna Feng ${ }^{2}$, Yan Chen ${ }^{3}$, Fiona Moir ${ }^{4}$, Christian U. Krägeloh ${ }^{5}$, Jennifer Hobson ${ }^{6}$, Craig S. Webster ${ }^{7}$

1. Associate Professor, University of Auckland, New Zealand; E-Mail: m.henning@auckland.ac.nz

2. Research Fellow, University of Auckland, New Zealand; E-Mail: joanna xy@hotmail.com

3. Lecturer, University of Auckland, New Zealand; E-Mail: yan.chen@auckland.ac.nz

4. Senior Lecturer, University of Auckland, New Zealand; E-Mail: $\underline{\text { f.moir@auckland.ac.nz }}$

5. Associate Professor, Auckland University of Technology, New Zealand; E-Mail: chris.krageloh@aut.ac.nz

6. Librarian, Philson Library, University of Auckland, New Zealand; E-Mail: jm.hobson@auckland.ac.nz

7. Associate Professor, University of Auckland, New Zealand; E-Mail: c.webster@auckland.ac.nz

* Correspondence: Marcus A. Henning; E-Mail: m.henning@auckland.ac.nz

Academic Editor: Peta Stapleton

Special Issue: Mind-Body Approaches that are Revolutionizing the Health Field

OBM Integrative and Complementary Medicine

2021, volume 6 , issue 4

doi:10.21926/obm.icm.2104033
Received: May 17, 2021

Accepted: September 22, 2021

Published: October 09, 2021

\begin{abstract}
This review examines the quality of the research exploring mindfulness within tai chi chuan and the way this integrative practice benefits health and learning for higher education students. A narrative review based on a systematic search was conducted. Ten English and three Chinese databases were utilised to appraise the relevant literature. The initial search identified 874 potentially appropriate English articles and 265 Chinese articles. A final review of 52 Chinese and 8 English articles was conducted. We used an evidence classification framework to determine the research rigour of the 60 articles (levels 1 to 4). We found that the majority of the studies reviewed were deemed to be either descriptive studies or based
\end{abstract}

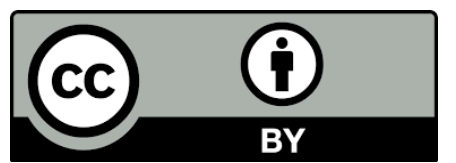

(C) 2021 by the author. This is an open access article distributed under the conditions of the Creative Commons by Attribution License, which permits unrestricted use, distribution, and reproduction in any medium or format, provided the original work is correctly cited. 
on opinion. From a narrative synthesis of patterns emerging within the purported benefits of tai chi chuan cited in the reviewed papers, we identified four clear categories, namely physiological outcomes, motor function and balance, learning, and psychological status. We found that more literature was published in Chinese than English, suggesting the need for reviews to be conducted across language databases. Moreover, we established that tai chi chuan as an integrative meditational exercise can enhance health and learning for higher education students.

\section{Keywords}

Mindfulness; tai chi chuan; higher education; narrative review

\section{Introduction}

Higher education is a system of learning that propagates many benefits whilst also having some challenges. The challenges faced by higher education students include managing one's time, living with debt, developing a balanced lifestyle, mental ill-health, physical ill-health, choosing an appropriate course of study, pressure of study and examinations, finding new friends, and living costs [1, 2]. These challenges sometimes become overwhelming and increase pressure on counselling and health services [2,3]. To address these challenges, it is important to consider groupbased methods that could assist learning, counselling and health services. There is evidence indicating that one group-based method, tai chi chuan (TCC), is being taught in higher education settings at both formal and informal levels. For example, in China TCC is often taught as part of a physical education curriculum [4], moreover one US university offers a course and qualification in TCC [5], and many universities offer informal co-curricular courses in TCC [6, 7]. Therefore, exploring the efficacy of TCC as an integrative meditation process is crucial to substantiating claims being made regarding its health and learning benefits.

In the current literature, there is a bourgeoning interest in mindfulness as a standalone, meditation practice [8-11]. Mindfulness practices have been linked to various positive health outcomes, such as developing a greater sense of relaxation, ameliorating the adverse impact of stress, enhancing concentration, and promoting healthy personal relationships $[8,12]$. It has been proposed at a conceptual level that the aim of self-cultivation in TCC is to become aware of three important facets, namely Yi (意 or mind), Qi (气), and Shen (神) [13, 14].

The concept of Yi refers to the idea of intention in which each movement is enacted with deliberate awareness and purpose. The idea of Qi or chi refers to the 'natural force or energy' and is associated with physiological and psychological functionality [15]. The idea of Shen is linked to the notion of spirit which is intertwined with the workings of the psyche [16]. Hence, mindfulness within this context refers to the state of integration of these essences, resulting in the phrase 'the mind motivates the chi, the chi mobilises the body' and a key facet underpinning the motivation is Shen [13]. Therefore, mindfulness within the TCC context refers to the awareness and cultivation of the integration of calmness, stillness, relaxation and sinking (or visualising the relaxation of the muscles) [14]. 
A preliminary review of the English language literature indicated a scarcity of research investigating TCC and its efficacy in relation to the higher education context. Nevertheless, one systematic review focussed on the higher education context, incorporating 76 studies and 9263 TCC participants [17]. In this review, they reported substantial evidence for the physical health and psychological benefits of higher education students engaging in TCC practice. This systematic review also revealed that the majority of research conducted in this area is being published in Chinese language journals. In a further pilot study, Wang and colleagues [18] reported benefits in the physical and mental health of university students in terms of increased vitality and greater emotional wellbeing. However, these studies do not address the importance of mindfulness within TCC. This distinction is important given that some schools teach TCC as a purely physical exercise regimen and do not focus on the meditative aspect of the process [19]. In this narrative review, we focused on mindfulness within TCC and how it promotes wellbeing and learning. In addition, the quality of evidence was assessed regarding the claims underlying the efficacy of this integrative process.

In this case, a narrative review is crucial as it enabled us to describe and interpret how the theory of TCC influences practice and whether the extant research substantiates the claims being made. Therefore, we had two questions driving this research, namely:

1. What is the quality of the research evidence associated with the investigation of the impact of mindfulness in TCC on students' wellbeing and learning in higher education?

2. What are the key health and learning benefits associated with this integrative practice (mindfulness meditation within TCC) in reference to higher education students?

\section{Materials and Methods}

\subsection{Search Process}

We chose a narrative review process, as we wanted to describe and evaluate all published articles with some consideration of the study methods employed [20]. Our review used the following criteria for narrative reviews [21]:

Types of participants: students undertaking study in a higher education tertiary setting.

Types of intervention: this narrative search considered any form of TCC intervention with an expressed mindfulness component. Qigong was not treated as TCC and was excluded from search strategies.

Types of outcome measures: mindfulness is an outcome of TCC, or mindfulness is linked to a reported outcome or health effect of TCC.

Initial searches were conducted during August 2017 in the Ovid databases Medline, Embase, and PsycINFO. Given the purported origins of TCC stemming from the Chinese region [9] we felt it important to investigate both the English and Chinese language evidence. Table 1 shows the variants for the keywords and phrases associated with TCC, mindfulness, and students.

Table 1 Keywords used in English-language database searches.

\begin{tabular}{lll}
\hline Tai Chi keywords & & \\
\hline tai chi & taiji & taijiquan \\
tai ji & t'aichi & t'ai chi \\
\hline
\end{tabular}




\begin{tabular}{lll}
\hline \multicolumn{2}{l}{ Mindfulness keywords } & \\
\hline $\begin{array}{l}\text { mindful* } \\
\text { meditat* }\end{array}$ & $\begin{array}{l}\text { attention } \\
\text { awareness } \\
\text { mind adj3 body }\end{array}$ & $\begin{array}{l}\text { concentrat* } \\
\text { focus* }\end{array}$ \\
\hline Student keywords & & \\
\hline student* & tertiary & Intern \\
freshm?n & faculty & Interns \\
post graduate* & school* & Trainee* \\
postgraduate* & universit* & Medical trainee* \\
graduate* & college* & \\
sophmore & polytech* & \\
education & technical school* & \\
\hline
\end{tabular}

Note: The asterisk $\left({ }^{*}\right)$ is used as a wildcard symbol to assist searching for terms that have similar prefixes, e.g., Meditat* will find meditation, meditator, meditators, meditational and so forth.

The final search strategies (see Table 2 for an exemplar of one search algorithm) were run on the $30^{\text {th }}$ of September 2017 in 10 English databases. This allowed broad coverage across disciplines. Ovid databases include AMED (1985-Present), Embase (1980-Present), Medline (1946-Present), PsycINFO (1806-Present) and SPORTDiscus (1975-Present). The EBSCOhost databases were CINAHL Plus (1937-Present), Education Research Complete (1880-Present), Eric (1966-Present) and ProQuest Education Database (1988-Present). All segments of the Cochrane Library were searched. Two authors (proficient in English and Chinese) developed and conducted the English database searches.

Table 2 Summary of search strategy: English-language databases (Medline, Embase, Psyclnfo, Eric).

Search terms (including subject headings from all databases):

tai chi/

tai ji/

(tai ji or taiji or taijiquan or tai chi).mp.

mindfulness/ or mindful*.mp.

meditation/ or meditat*.mp

mind adj3 body.mp.

exp student/

exp Students/

library schools/ or exp schools, health occupations/ or universities/

school/ or college/ or community college/ or medical school/ or pharmacy school/ exp education/

schools/ or academic settings/ or exp colleges/ or graduate schools/ or institutional schools/ or military schools/ or technical schools/ 
exp higher education/ or nursing education/ or social work education/ or exp teacher education/ or exp curriculum/ or education, predental/ or education, premedical/ or exp education, professional/

exp Faculty/

(student* or post graduate* or postgraduate* or graduate* or freshm?n or sophomore or trainee* or intern or interns).mp.

(universit* or college* or faculty or school* or polytech* or higher education or tertiary).mp.

[Note: T'ai Chi etc, yielded no new results in the OVID databases]

Three leading Chinese databases were searched on $4^{\text {th }}$ of October 2017: China Academic Journals (CAJ), Wanfang, and the National Central Library of Taiwan (NCL). Search strategies used the Chinese characters that corresponded to the main English concepts of mindfulness, TCC, and university student. Traditional Chinese character forms were used in NCL, and simplified Chinese characters were used in CAJ, and Wanfang. Two authors developed and conducted the Chinese database searches.

In addition to database searches, the reference lists of included studies were hand searched, and additional studies were selected for inclusion if relevant. A search via Google Scholar was conducted by using the 'cited by' facility. All studies that cited an included study were evaluated and selected for inclusion if relevant.

\subsection{Study Selection}

References were stored in the reference management software EndNote (version X7; Clarivate Analytics, Philadelphia, United States).

The following steps outline the study selection process and the inclusion/exclusion criteria:

1. Duplicate studies were removed.

2. Studies published in English and Chinese languages were included. Studies published in other languages were excluded due to resource limits.

3. Both qualitative and quantitative studies were included. The following types of publications were excluded: grey literature, books, book chapters, newspaper articles, and magazine articles. Research theses were included.

4. Two authors independently reviewed article titles and abstracts. Studies were selected for full text assessment based on consensus between these authors. If a consensus was not reached, the article was included for full text assessment.

5. Two authors independently retrieved and reviewed the full texts of selected studies. Inclusion of articles in the evidence synthesis was based on a consensus between these reviewers. Disagreements were discussed among the whole research team until a consensus was reached.

6. Hand-searched articles were evaluated and nominated following the same selection process.

\subsection{Data Analysis}

The decision-making process of the articles for each stage of the review was documented using the Preferred Reporting Items for Systematic Reviews and Meta-Analyses (PRISMA) guidelines [22] 
as shown in Figure 1. The levels of evidence used to determine the quality of each article were based on the criteria shown in Table 3 [23].

A final summary table was developed, which included both the Chinese and English language articles relevant to this search. Two Chinese language speakers were able to translate and summarise the main findings of the Chinese studies, whilst all authors reviewed the English studies.

The summary table was developed through adapting criteria employed in other narrative reviews [e.g., 24]. The key elements chosen for this review and relevant to this field of study were: (1) evidence level, study type and incorporation of mindfulness; (2) author (date); and (4) key outcomes. The salient themes and patterns emerging from the key findings of the final reviewed articles were analysed using a narrative synthesis approach and key categories were identified [25].

\section{Results}

\subsection{Summary of the Search Strategy}

The number of initial hits generated from English databases was much higher than that from Chinese databases, although fewer English articles were included into the subsequent evidence synthesis (Figure 1). English databases generated 874 articles in total, of which eight articles were written in Chinese, and 866 articles were in English or other languages. Two hundred and fifty-five Chinese-language articles were identified through Chinese databases. In total, there were 263 Chinese-language articles in this review, including eight Chinese-language articles from English databases.

The selection process for English-language articles started with 866 articles. After removing duplicates and articles not meeting the inclusion criteria regarding their titles and abstracts, 48 articles remained for full text assessment. Forty articles were then discarded as they were deemed out of scope, and thus eight articles were selected for final analysis. In reference to the Chineselanguage articles, 93 articles remained for the full text assessment. Among the 93 articles, 37 articles were included into the final analysis. Hand searching added a further 15 Chinese-language articles. In total, 60 articles including 52 Chinese-language articles and eight English-language articles were selected for final appraisal. 


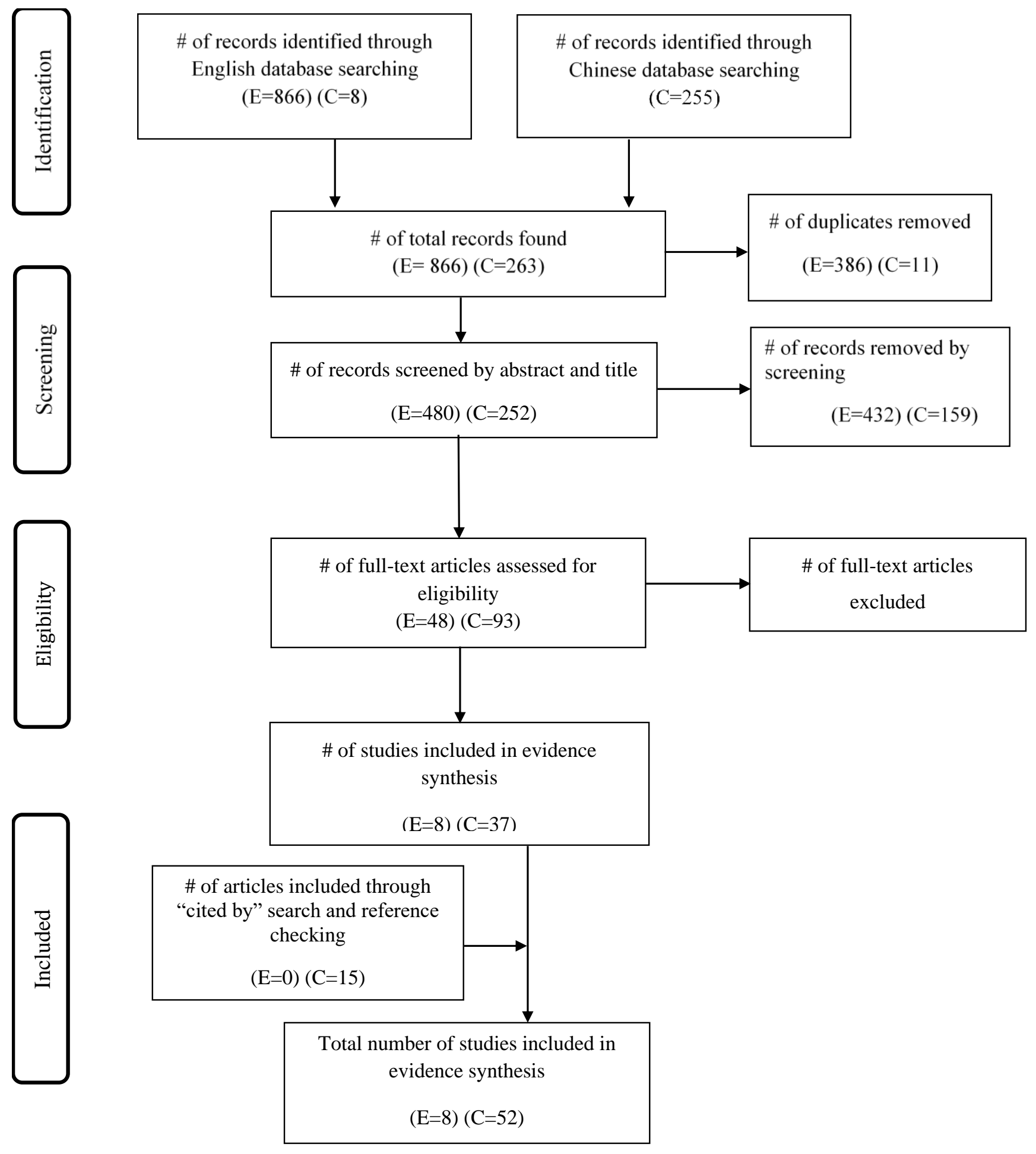

Figure 1 Combined flow diagram for Chinese (C) and English (E) database searches.

\subsection{Levels of Evidence}

As shown and described in Table 3, the reviewed articles were classified using a previously published evidence-quality classification system [23]. No articles at the highest level of evidence, 
i.e., level 1a (meta-analysis of randomised controlled studies) were found. However, both Chinese and English-language articles using randomisation and a control group in their study designs were identified i.e., level $1 b(n=5)$. Chinese and English-language empirical studies were identified as levels $2 \mathrm{a}$ and $2 \mathrm{~b}(n=14)$, using either a non-randomised control group or incorporating a quasiexperimental design. The majority of studies reviewed were designated level 3 or 4 (respectively, non-experimental descriptive studies and reports of expert opinion, $n=41$ ).

Table 3 Levels of evidence: Classification system adapted from Jensen et al [23].

\begin{tabular}{lll}
\hline $\begin{array}{l}\text { Level } \\
\text { evidence }\end{array}$ & Description of classification & $\begin{array}{l}\text { No. of studies } \\
(n=60)^{*}\end{array}$ \\
\hline $1 a$ & Evidence from meta-analysis of randomized controlled trials & $C=0$ \\
& & $E=0$ \\
$1 b$ & Evidence from at least one randomized control trial & $C=4$ \\
& & $E=1$ \\
$2 a$ & Evidence from at least one controlled study without & $C=4$ \\
& randomization & $E=2$ \\
& Evidence from at least one other type of quasi-experimental & $C=7$ \\
3 & study (for example one-group, pre-test, post-test studies) & $E=1$ \\
& Evidence from non-experimental descriptive studies, such as & $C=7$ \\
4 & comparative studies, correlation studies and case-control studies & $E=3$ \\
& Evidence from expert committee reports or opinions and/ or & $C=30$ \\
& clinical experience of respected authorities & $E=1$ \\
\hline
\end{tabular}

*Number of reports: $\mathrm{E}=$ English, $\mathrm{C}=$ Chinese.

\subsection{Overall Summary of the Reviewed Articles}

The key elements of the studies included in the review are shown in Table 4. All authors of the articles highlighted the usefulness of the synthesis of mindfulness meditation and TCC as an intervention within the higher education context, thus fulfilling the requirements for inclusion in our review. The key outcomes from these articles were analysed (Table 4), resulting in four categories (or themes) summarising the purported benefits of TCC with a mindfulness component:

1. Physiological outcomes

2. Motor function and balance

3. Learning

4. Psychological status

Table 4 Summary of the articles included in the final review $(n=60)$.

\begin{tabular}{ll}
\hline $\begin{array}{l}\text { Evidence level, Author (date) } \\
\text { study type and }\end{array}$ & Key outcomes \\
incorporation of & \\
mindfulness & \\
\hline $\begin{array}{ll}\text { 1b. Randomised } \\
\text { control trial }\end{array}$ & Improved motivated to learn and understanding of TCC. \\
\hline
\end{tabular}




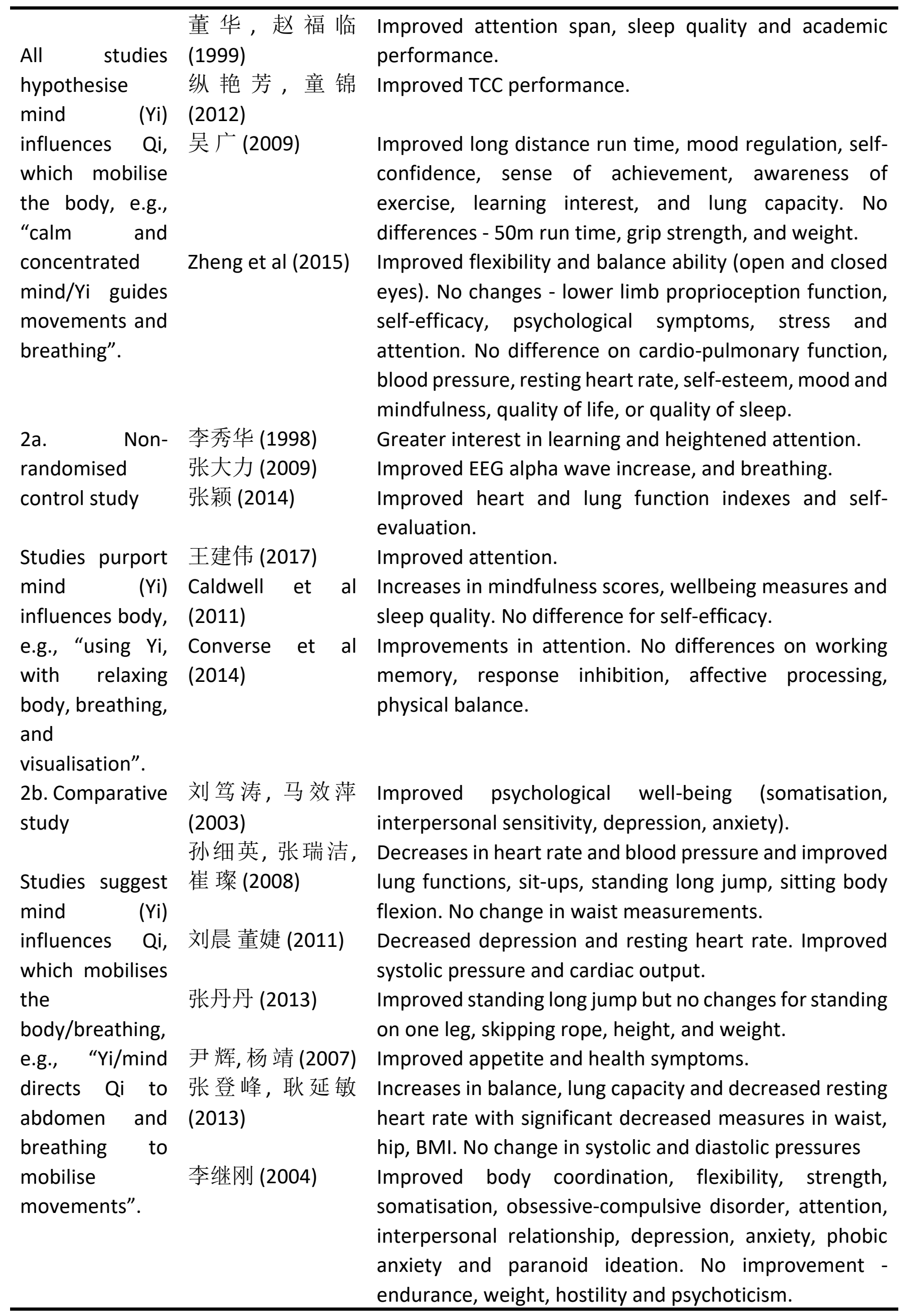




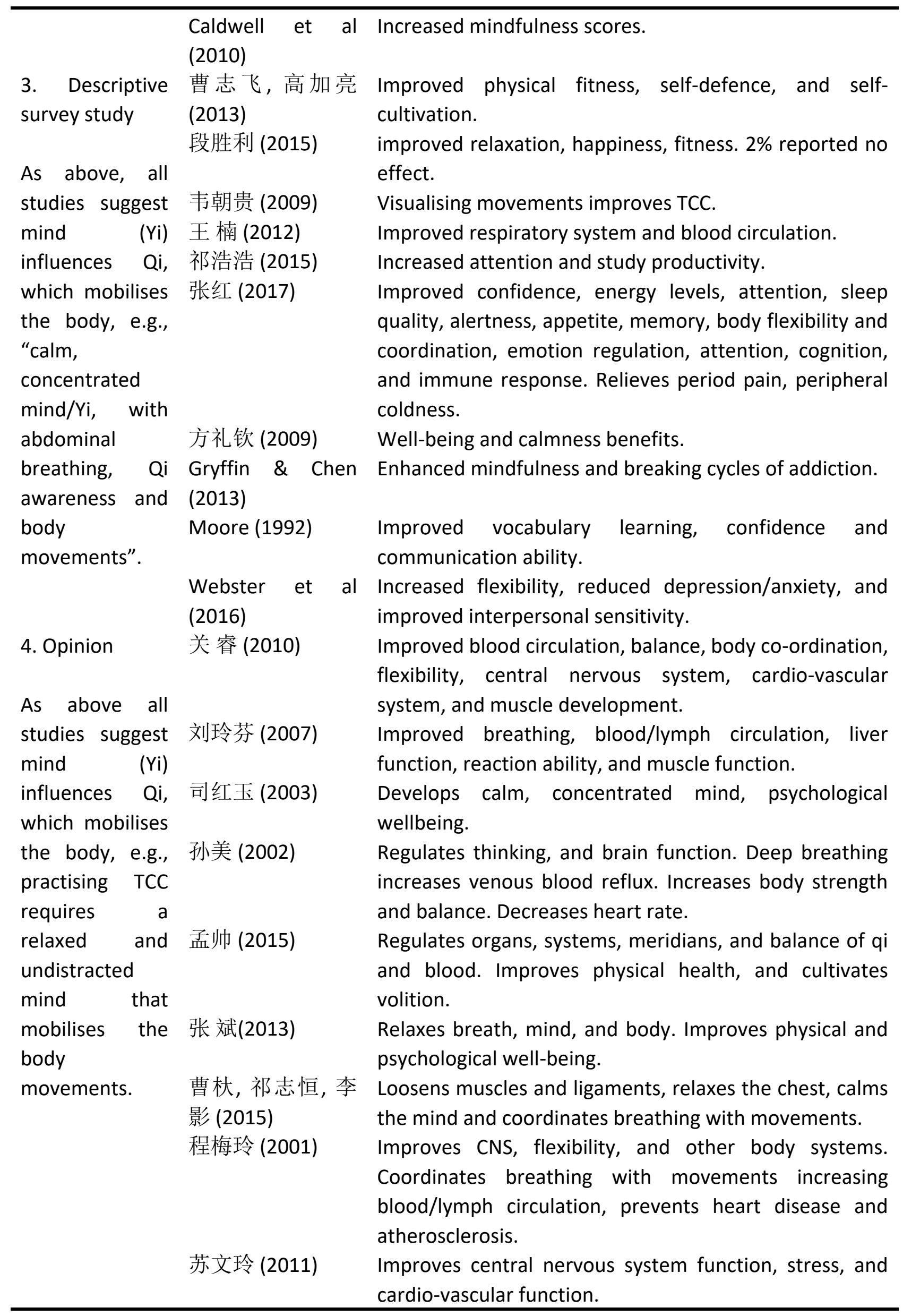




\begin{tabular}{|c|c|}
\hline 邱金昌(2008) & $\begin{array}{l}\text { Improves central nervous system and internal organs, } \\
\text { confidence and mental health. }\end{array}$ \\
\hline 陈孝道 (2010) & $\begin{array}{l}\text { Improves mental health, blood/lymph flow, and cardio- } \\
\text { vascular function. }\end{array}$ \\
\hline 陈清富(2014) & $\begin{array}{l}\text { Improves heart/lung function, blood circulation, and and } \\
\text { mental health. }\end{array}$ \\
\hline $\begin{array}{l}\text { 黄兴裕, 吴秀华, } \\
\text { 黄海 (2013) }\end{array}$ & $\begin{array}{l}\text { Improves psychological wellbeing, muscle strength, } \\
\text { response time, balance, oxygen uptake, heart rate, and } \\
\text { sympathetic and parasympathetic function. }\end{array}$ \\
\hline 张丽丽(2015) & Improves motor, respiratory, and nervous systems. \\
\hline $\begin{array}{l}\text { 杨晓敏, 张宏䂞, } \\
\text { 牛大三(2003) }\end{array}$ & $\begin{array}{l}\text { Improves blood circulation, mind-body awareness and } \\
\text { energy. }\end{array}$ \\
\hline 王利 (2012) & $\begin{array}{l}\text { Cultivates awareness of movements and increases } \\
\text { creativity. }\end{array}$ \\
\hline 酉杰峰(2010) & $\begin{array}{l}\text { Improves fatigue, cardio-vascular function and other } \\
\text { bodily functions. }\end{array}$ \\
\hline 于晓红(2016) & $\begin{array}{l}\text { Eliminates discursive thoughts. Improves concentration } \\
\text { and mindfulness. }\end{array}$ \\
\hline 冯玉娟 (2010) & $\begin{array}{l}\text { Reduces depression. Improves breathing, microvascular } \\
\text { circulation, lung capacity and cardiac function. }\end{array}$ \\
\hline 刘后振 (2004) & $\begin{array}{l}\text { Assists with conflict management, depression, mood } \\
\text { control, and anxiety. }\end{array}$ \\
\hline 王向阳 (2007) & $\begin{array}{l}\text { Improves the body immunity, blood circulation, energy, } \\
\text { and joint function. Prevents disease, strengthens } \\
\text { bones/tendons. }\end{array}$ \\
\hline 田慧芳 (2011) & $\begin{array}{l}\text { Benefits central nervous system, human body systems } \\
\text { and organs. }\end{array}$ \\
\hline 高清 伟 (2004) & $\begin{array}{l}\text { Improve memory, concentration, mental productivity, } \\
\text { psychological well-being, sleep quality and sensory } \\
\text { function. }\end{array}$ \\
\hline 张荣清 (2011) & $\begin{array}{l}\text { Cultivates mental relaxation, happiness, self-esteem, and } \\
\text { self-confidence. }\end{array}$ \\
\hline $\begin{array}{l}\text { 朱继华，程梅玲 } \\
\text { (2004) }\end{array}$ & $\begin{array}{l}\text { Benefits physical and psychological health. Beneficial to } \\
\text { central nervous system and improves other } \\
\text { systems/organs. Enhances breathing, blood/lymph } \\
\text { circulation and cardiovascular and immune systems. }\end{array}$ \\
\hline 李瑛 (2009) & $\begin{array}{l}\text { Benefits central nervous system and other } \\
\text { systems/organs. Regulates mood, anxiety and/or } \\
\text { stressed. }\end{array}$ \\
\hline 杨旭杰 (2013) & $\begin{array}{l}\text { Improves mood states, cardiopulmonary activity, central } \\
\text { nervous system, and respiratory/blood circulation. }\end{array}$ \\
\hline 王红梅 (2008) & $\begin{array}{l}\text { Ameliorates stress, anxiety and depression. Engenders } \\
\text { energy, concentration, confidence, and calmness. }\end{array}$ \\
\hline 马否 (2011) & Enhances emotional regulation and physical health. \\
\hline
\end{tabular}




$\begin{array}{ll}\text { 王居河 (2017) } & \begin{array}{l}\text { Improves physical and psychological well-being, } \\ \text { immunity, and sleep quality. }\end{array} \\ \text { Zheng et al (2014) } & \text { Design for the Zheng et al (2015) study. }\end{array}$

The key beneficial outcomes, associated with the synthesis of mindfulness and TCC as applied within a higher education setting, and linked to the highest reviewed level of evidence ( $1 \mathrm{~b}$, see Table 5) [26-30] are: (1) specific physiological benefits (e.g., improved sleep quality, and increased lung function); (2) motor function and balance improvement (e.g., improved balance whilst moving); (3) learning enhancements (e.g., increased attention capability and learning motivation); and (4) improved psychological status (e.g., enhanced mood management). Nonetheless, there were studies [26, 30] reporting no statistically significant differences (i.e. $p>0.05$ ), such as in relation to cardio-pulmonary function, blood pressure, resting heart rate, self-esteem, mood and mindfulness, quality of life, or quality of sleep.

Table 5 Selected characteristics of Randomised Control Trial studies demarcated as $1 \mathrm{~b}$ in Table 4.

\begin{tabular}{|c|c|c|c|c|c|}
\hline Study & $\begin{array}{l}\text { Country } \\
\text { (region) }\end{array}$ & Intervention & Control & $\mathrm{N}$ & Measures \\
\hline $\begin{array}{l}\text { 李 珍 } \\
\text { (2009) }\end{array}$ & $\begin{array}{l}\text { China } \\
\text { (Gansu } \\
\text { province) }\end{array}$ & $\begin{array}{l}\text { Focusing on "Yi" of } \\
\text { Eight-form TCC (music } \\
\text { and mnemonic phrases } \\
\text { assisted learning) prior } \\
\text { to learning } 24 \text {-form TCC } \\
\text { for } 13 \text { weeks in total }\end{array}$ & $\begin{array}{l}\text { 24-form Tai Chi } \\
\text { Chuan only for } \\
13 \text { weeks }\end{array}$ & 60 & $\begin{array}{l}\text { Tai Chi Chuan } \\
\text { performance test, number } \\
\text { of students voluntarily } \\
\text { practising TCC }\end{array}$ \\
\hline $\begin{array}{l}\text { 董华, } \\
\text { 赵 福 } \\
\text { 临 } \\
\text { (1999) }\end{array}$ & $\begin{array}{l}\text { China } \\
\text { (Fujian } \\
\text { province) }\end{array}$ & $\begin{array}{l}24 \text {-form TCC } 20-25 \\
\text { minute sessions, every } \\
\text { morning for two months }\end{array}$ & $\begin{array}{l}\text { No Tai Chi } \\
\text { Chuan } \\
\text { intervention }\end{array}$ & 160 & $\begin{array}{l}\text { Attention span, academic } \\
\text { performance }\end{array}$ \\
\hline $\begin{array}{l}\text { 纵 艳 } \\
\text { 芳, 童 } \\
\text { 锦 } \\
(2012)\end{array}$ & $\begin{array}{l}\text { China } \\
\text { (Anhui } \\
\text { province) }\end{array}$ & $\begin{array}{l}\text { Visualising each } \\
\text { movement of 24-form } \\
\text { TCC before practising } \\
\text { them for four months }\end{array}$ & $\begin{array}{l}\text { Only } 24 \text {-form } \\
\text { TCC for four } \\
\text { months }\end{array}$ & 160 & $\begin{array}{l}\text { Theory test of TCC, } \\
\text { performance test of TCC, } \\
\text { and technique } \\
\text { assessment of TCC }\end{array}$ \\
\hline $\begin{array}{l}\text { 吴 广 } \\
(2009)\end{array}$ & $\begin{array}{l}\text { China } \\
\text { (Sichuan } \\
\text { province) }\end{array}$ & $\begin{array}{l}\text { Mindful breathing and } \\
\text { practice of } 24 \text {-form TCC } \\
\text { for one semester of } \\
\text { formal TCC class }\end{array}$ & $\begin{array}{l}\text { Only physical } \\
24-\text { form TCC } \\
\text { for a semester } \\
\text { of Tai Chi } \\
\text { Chuan class }\end{array}$ & 270 & $\begin{array}{l}\text { Physical exercise } \\
\text { measures, body mass } \\
\text { index, interest in TCC, } \\
\text { understanding } \\
\text { performance facets of TCC }\end{array}$ \\
\hline $\begin{array}{l}\text { Zheng } \\
\text { et al } \\
(2015)\end{array}$ & $\begin{array}{l}\text { China } \\
\text { (Fujian } \\
\text { province) }\end{array}$ & $\begin{array}{l}\text { Tai Chi Chuan } 60 \text {-minute } \\
\text { sessions, five days per } \\
\text { week for } 12 \text { weeks }\end{array}$ & $\begin{array}{l}\text { No specific } \\
\text { exercise } \\
\text { intervention }\end{array}$ & 206 & $\begin{array}{l}\text { Balance ability, lower limb } \\
\text { proprioception, flexibility, } \\
\text { psychological symptoms, } \\
\text { self-efficiency, cardio- } \\
\text { pulmonary function, and } \\
\text { stress. }\end{array}$ \\
\hline
\end{tabular}


According to level 2 studies [31-44], similar benefits were reported. These included (1) physiological benefits (e.g., improved sleep quality and cardiovascular function); (2) motor function and balance (e.g., improvements on sit-ups, standing long jump, and sitting body flexion); (3) learning enhancements (e.g., inspired their learning interest); and (4) improved psychological status (e.g., interpersonal relationship, depression, anxiety, phobic anxiety and paranoid ideation). In contrast, some studies $[35,36]$ showed no significant differences in terms of measures associated with working memory, response inhibition, affective processing, physical balance, self-regulation, and self-efficacy.

Non-experimental studies (level 3) [17, 45-53] and articles based on expert opinion (level 4) [5484] purported claims consistent with the outcomes from the higher levels of evidence. These studies reinforced physiological, motor function, learning and psychological benefits. Nonetheless, some non-aligned studies made assertions that were descriptive such as breaking cycles of addiction [52], mastery of vocabulary, and improving the ability to communicate [53].

\section{Discussion}

This review explored the scholarly literature situated in refereed journals that described the importance of mindfulness within TCC and how this integrative system influenced health and learning amongst higher education students. The majority of the literature was opinion-based and thus deemed low in methodological rigour [23]. Nonetheless, this literature was a rich source of narrative as it elucidated the theory behind the utilisation of TCC. The papers incorporating robust research design somewhat validating these conceptual discourses. Therefore, the narratives described the interaction between the conceptual elements of TCC, its practice, and links to purported health and learning outcomes. The evidence for the meditational influence is purported in the Chinese literature although considerable work needs to be done in the form of more lifespan longitudinal work.

The concept and practice of mindfulness as applied to the context of TCC involves the awareness of the integration of $\mathrm{Yi}$, Shen and Qi. In this review of the literature, there are many examples within the articles appraised [e.g., 59, 62, 69] that have referred to the activation or development of the $\mathrm{Yi}$ as being critical to developing a deep understanding of how the body is mobilised. These results are consistent with the classical order, as put forward by the notable tai chi expert Cheng Man-Ch'ing, that states the mind directs the Qi, which in turn mobilises the body [13].

To evaluate the efficacy of this integrative practice, the quality and origins of research evidence were reviewed and this enabled us to comment on the purported health and learning benefits for higher education students.

\subsection{Quality and Origins of Research Evidence}

As shown in Tables 3 and 4, the majority of the evidence (87\%) reviewed in this study was written in Chinese. In addition, the evidence is mostly descriptive (levels 3 and $4, n=41,68 \%$ ) with only five studies (8\%) being classified as level $1 \mathrm{~b}$ and none at $1 \mathrm{a}$, and 14 studies (23\%) classified as level 2. This suggests that very few studies used rigorous research protocols, which is surprising given that it has been estimated that 2.5 million individuals practise TCC in the USA alone [85].

The randomised controlled trials (RCTs) reviewed in this study were mainly conducted in Chinese, with only one in English. The challenge when applying RCTs to the determination of efficacy of TCC 
is controlling and matching for factors such as interest, motivation, kinaesthetic and tactile aptitude, personality, state of relaxation, capacity to concentrate, teacher characteristics and expertise, the learning environment, and number of hours involved in formal and individual practice $[9,13,86]$. Therefore, a definitive investigation of the benefits of TCC, especially with a focus on a higher education context, requires a series of studies using different research methodologies to investigate the impact of these underlying factors.

\subsubsection{Key Outcomes for Higher Education Students}

The papers in our review distinctly suggest that the integrative nature of TCC has positive health and learning benefits for higher education students. According to the reports described in papers with quality evidence (levels 1 and 2), the benefits include: (1) improved attention span and academic performance [27]; (2) enhanced self-confidence, sense of achievement, awareness of exercise, learning interest [29]; (3) increased motivation to learn [31]; (4) better psychological wellbeing, i.e., such as, improvements in interpersonal sensitivity, depression, and anxiety [37, 44]; and (5) improved sleep quality [26].

It is likely that when mindfulness and movement are synthesised, TCC becomes more focussed [87]. In TCC, the movements are slow and precise and with the explicit inclusion of the teaching of meditation, this allows practitioners to attain both mental and physical benefits, with low risk of injury. As with other mind-body systems, TCC with a strong meditation focus unites awareness of thinking, sensing and moving [87]. These benefits suggest that an integrative approach leads to beneficial health and educational outcomes.

\subsection{Implications for Teaching and Learning TCC}

Our review has shown that mindfulness embedded within TCC results in positive health and learning outcomes for higher education students. Nevertheless, we can surmise from the articles we have reviewed that this view of TCC is a multi-faceted system, which makes it difficult to ascertain the 'real' benefit of each facet. Furthermore, a lifelong commitment is required to develop the integrative and accomplished level of TCC practice resulting in a calm, concentrated mind state (Yi), synthesised with abdominal breathing and Qi awareness to mobilise body movements [48]. This suggests that teaching the full spectrum of TCC to higher education students is challenging.

To deliver a principled transmission of TCC requires teachers to be honest about the length of training and effort required to achieve higher levels of expertise. Even though some authors suggest that TCC can be learned in a short period of time [88], the treatise by Man-Ch'Ing [13] on TCC describes the complexity of the teaching and learning process. It is relatively easy to learn the basic movements of the form (body level and breathing) [88], but integrating these with Yi and Qi may take a lifetime or several lifetimes $[13,14,89]$. In the empirical studies cited in this review, the interventions were over a very short time due to research feasibility, hence lifespan research is required to tease out the long term benefits of integrative TCC practice.

As stated by Yang and colleagues [90] there is immense variability in the way TCC is taught. This makes comparative research difficult given the apparent lack of standardisation across methods. As such, there is little consistency in terms of delivery of TCC, length and frequency of training required to show a positive TCC effect, and how the duration of TCC practice contributes to a meaningful outcome. In their bibliometric analysis of the published data in the area of TCC, Yan and colleagues 
[90] found that "10.4\% of included primary studies had more than one Tai Chi group with the aim of evaluating the potential benefits, advantages and/or acceptability of the different styles, forms, frequencies, duration, delivery modes and settings for the target population." They noted there was some consistency in the teaching of TCC, in that most studies reviewed showed that sessions lasted about 60 minutes in duration and practice occurred around two to three times per week usually lasting 3 to 6 months. However, they noted that intensity of TCC training was variable and the influence of individual differences between teachers and participants was difficult to measure. They further suggested that studies in the future investigate the notion of the multifactorial nature of the dose-response effects of TCC, and consider more fine grained analysis of the reporting of contextual and participatory elements around service delivery. Therefore, the challenges to research in this area are linked to reporting adequate information about the many variables involved in the teaching process, such as the instructor's capability and experience, the various factors influencing the dissemination and learning of the skills and knowledge, and evaluating the desired outcome/s of teachers and learners.

In addition, Klein and Adams (91) explored the feasibility of facilitating a programme incorporating TCC. They suggested that exercise persistence and cost effectiveness need to be considered. They found that TCC persistence in diabetic management and cardiac rehabilitation programmes was low (10\% to $50 \%$ ). This is an issue that needs to be considered when purporting the benefits of TCC and is especially significant when applied to the higher education setting, given the demands and distractions of student life. Therefore, if classes are presented as an informal option it is likely that only a few students will persist.

If, however, the programme is embedded within the curriculum the impact will likely be longer lasting [92]. To advocate a compulsory inclusion suggests that TCC (as a meditative movement process) is an optimal form of exercise. This begs the question, how is the integrative version TCC (meditation in motion) better or different to other mind-body practices (e.g., Yoga and Pilates)? From this review, there appears to be very few studies conducted in the higher education context that compares the integrative practice of TCC with other exercise regimens, which suggests that formal inclusion should be treated with caution until more comparative research has been conducted.

\section{Conclusions}

This narrative review has enabled us to make several assertions about mindfulness and TCC in relation to the higher education context. First, the quality of evidence was skewed towards opinion articles. This is likely due to the difficulty with conducting comparative longitudinal studies and problems associated with attrition, ensuring randomisation, and allocation concealment. Second, Chinese investigation and subsequent publications regarding the efficacy and use of TCC far exceeds (both in quality and frequency) Western investigation, underscoring the importance of including this body of literature in any review of this topic. Third, the health and learning benefits of engaging in an integrative approach to TCC are being established. For TCC to be accepted as a formal inclusion in curricula, TCC needs to be investigated further especially in terms of its relative efficacy and costbenefit assurance in comparison to other exercise and meditation practices. 


\section{Author Contributions}

All authors contributed to the conception or design of the work analysis, and interpretation of data for the work. All authors contributed to the drafting of the work and revising it critically for important intellectual content. All authors contributed to the final approval of the version to be published. All authors agree to be accountable for all aspects of the work in ensuring that questions related to the accuracy or integrity of any part of the work are appropriately investigated and resolved. Three authors (XJF, YC, JH) were involved in the initial acquisition of the papers for review.

\section{Funding}

The authors disclose the receipt of a grant approved by the University of Auckland, School of Medicine PBRF Committee 2017 (Project code: 71603) to cover the salary of the Research Fellow (XJF). The funders were not involved in the study design and execution, data collection and analysis, or the manuscript preparation or final editing.

\section{Competing Interests}

The authors have declared that no competing interests exist.

\section{References}

1. Gates G. Ten common problems students face in college [Internet]. Owlcation; 2015. Available from: https://owlcation.com/academia/common-problems-for-college-students.

2. Kitzrow MA. The mental health needs of today's college students: Challenges and recommendations. J Women High Educ. 2003; 41: 167-181.

3. Stone GL, Archer Jr J. College and university counseling centers in the 1990s: Challenges and limits. Couns Psychol. 1990; 18: 539-607.

4. Huang Y. Based on the statistical analysis of taijiquan culture heritage and development of colleges and universities. Proceedings of the 2016 National Convention on Sports Science of China; 2016 September 23-25; Zhengzhou, China. Les Ulis, France: EDP Sciences.

5. College of Tai Chi [Internet]. Sunnyvale, CA: University of East-West Medicine; 2021. Available from: https://uewm.edu/programs/taichicollege.

6. Confucius institute: Courses [Internet]. Canterbury, New Zealand: Universty of Canterbury; 2021. Available from: https://www.canterbury.ac.nz/arts/research/ci/courses/.

7. Tai Chi Chuan for musicians [Internet]. Boston, Massachusetts: Berklee College of Music; 2021. Available from: https://college.berklee.edu/courses/psh-260.

8. Davis DM, Hayes JA. What are the benefits of mindfulness? A practice review of psychotherapyrelated research. Psychotherapy. 2011; 48: 198-208.

9. Henning MA, Krägeloh CU, Webster C. Mindfulness and Taijiquan. Ann Cogn Sci. 2017; 1: 1-6.

10. Kabat-Zinn J. Mindfulness-based interventions in context: Past, present, and future. Clin Psychol (New York). 2003; 10: 144-156.

11. Zeidan F, Johnson SK, Diamond BJ, David Z, Goolkasian P. Mindfulness meditation improves cognition: Evidence of brief mental training. Conscious Cogn. 2010; 19: 597-605.

12. Grossman P, Niemann L, Schmidt S, Walach H. Mindfulness-based stress reduction and health benefits: A meta-analysis. J Psychosom Res. 2004; 57: 35-43. 
13. Man-Ch'Ing C. Master Cheng's thirteen chapters on Tai Chi Ch'üan. New York: Sweet Ch'i Press; 1982.

14. Wee KJ. Taijiquan Wuwei: A natural process. Auckland, New Zealand: Taijiquan School of Central Equilibrium; 2003.

15. Jahnke R, Larkey L, Rogers C, Etnier J, Lin F. A comprehensive review of health benefits of qigong and tai chi. Am J Health Promot. 2010; 24: e1-e25.

16. Gu MD. The theory of the dao and taiji: A chinese model of the mind. J Chin Philos. 2009; 36: 157-175.

17. Webster CS, Luo AY, Krageloh C, Moir F, Henning M. A systematic review of the health benefits of Tai Chi for students in higher education. Prev Med Rep. 2016; 3: 103-112.

18. Wang YT, Taylor L, Pearl M, Chang LS. Effects of Tai Chi exercise on physical and mental health of college students. Am J Chin Med. 2004; 32: 453-459.

19. Qin L, Au S, Choy W, Leung P, Neff M, Lee K, et al. Regular Tai Chi Chuan exercise may retard bone loss in postmenopausal women: A case-control study. Arch Phys Med Rehabil. 2002; 83: 1355-1359.

20. Ferrari R. Writing narrative style literature reviews. Med Writ. 2015; 24: 230-235.

21. Systematic reviews - research guide. Perth, Western Australia: Murdoch University; 2019. Available from: https://libguides.murdoch.edu.au/systematic/PICO.

22. Moher D, Liberati A, Tetzlaff J, Altman DG. Preferred reporting items for systematic reviews and meta-analyses: The PRISMA statement. Ann Intern Med. 2009; 151: 264-269.

23. Jensen L, Merry A, Webster CS, Weller J, Larsson L. Evidence-based strategies for preventing drug administration errors during anaesthesia. Anaesthesia. 2004; 59: 493-504.

24. Best $P$, Manktelow R, Taylor B. Online communication, social media and adolescent wellbeing: A systematic narrative review. Child Youth Serv Rev. 2014; 41: 27-36.

25. Ryan R. Cochrane Consumers and Communication Review Group: Data synthesis and analysis [Internet]. London: Cochrane Consumers and Communication; 2013. Available from: http://cccrg.cochrane.org/sites/cccrg.cochrane.org/files/public/uploads/Analysis.pdf.

26. Li Z. Research on using the priority of learning and cooperation teaching model of eight-style taijiquan "lianyi" to improve the effect of taijiquan teaching. J Yichun Univ. 2009; 31: 166-168.

27. Dong H, Zhao FL. An experimental study on the relationship between Taijiquan practice and university students' academic performance. J Shanghai Phys Educ Inst. 1999; 23: 125-126.

28. Zong YF, Tong J. An experimental study on the application of visualization training in the teaching of elective Taijiquan classes in ordinary colleges and universities. J Hubei Univ Econ (Human Soc Sci). 2012; 9: 223-224.

29. Wu G. An experimental study on "mindful breathing" in Taijiquan teaching in colleges and universities. Acad J Shaolin Taiji (Zhongzhou Sports). 2009; 2: 58-60.

30. Zheng G, Lan X, Li M, Ling K, Lin H, Chen L, et al. Effectiveness of Tai Chi on physical and psychological health of college students: Results of a randomized controlled trial. PLoS One. 2015; 10: e0132605.

31. Li XH. Application of music and attention principle to Taichichuan teaching. J Tianjin Inst Phys Educ. 1998; 13: 97-98.

32. Zhang DL. Experimental study on the impact of taijiquan on EEG a wave of female college students. Sports Forum. 2009; 1: 68-69. 
33. Zhang Y. Taijiquan teaching design in ordinary university students' health promotion context. Beijing: Capital Institute of Physical Education; 2014.

34. Wang JW. Experimental research on the attention control training of college Taijiquan teaching. Sport Sci Technol. 2017; 38: 145-146.

35. Caldwell K, Emery L, Harrison M, Greeson J. Changes in mindfulness, well-being, and sleep quality in college students through taijiquan courses: A cohort control study. J Altern Complement Med. 2011; 17: 931-938.

36. Converse AK, Ahlers EO, Travers BG, Davidson RJ. Tai chi training reduces self-report of inattention in healthy young adults. Front Hum Neurosci. 2014; 8: 13.

37. Liu DT, Ma XP. The influence of Taijiquan on the mental health of college (university) students. Mod Rehabil. 2003; 7: 2252.

38. Sun XY, Zhang RJ, Cui C. Influence to Taijiquan to non-sports major female university student's healthy in mind and body. BOJI(WUSHUKEXUE). 2008; 5: 42-44.

39. Liu C, Dong J. Traditional Chinese sports and health care relieve depression in university students. Sports World Sch. 2011; 7: 54-56.

40. Zhang DD. Improving the ability of clinical students of Capital Medical University to maintain the core stability of the body. Beijing: Beijing University of Physical Education; 2013.

41. Yin $\mathrm{H}$, Yang J. Rehabilitative effects of Taichi exercise on the subhealthy status of college students. J Clin Rehabil Tissue Eng Res. 2007; 11: 7991-8001.

42. Zhang DF, Geng YM. The effect of aerobic exercise programs based on yoga and Taijiquan on physique and physical health of university students. Sport. 2013; 58: 54-56.

43. Caldwell K, Harrison M, Adams M, Quin RH, Greeson JM. Developing mindfulness in college students through movement-based courses: Effects on self-regulatory self-efficacy, mood, stress, and sleep quality. J Am Coll Health. 2010; 58: 433-442.

44. Li JG. A research into the effects of 'Taijiquan' on the physical and mental health of university undergraduates. J Guangdong Educ Inst. 2004; 24: 126-128.

45. Cao ZF, Gao JL. A preliminary study on the teaching "Yi" of Taijiquan. Contemp Sports Technol. 2013; 11: 125-127.

46. Duan SL. The development of twenty-four simplified Taijiquan in colleges and universities and the countermeasures--A case study of Zhengzhou University SIAS International College. BOJI(WUSHUKEXUE). 2015; 12: 57-58.

47. Wei ZG. Current situation of Taijiquan teaching and countermeasures in ordinary colleges and universities. Sports World Sch. 2009; 4: 15-16.

48. Wang N. Fitness value of Taijiquan. J Jilin Inst Phys Educ. 2012; 28: 140-142.

49. Qi HH. Current situation and countermeasures of Taijiquan teaching in public physical education classes in ordinary colleges and universities in Wuhan City. Wuhan: Central China Normal University; 2015.

50. Zhang $\mathrm{H}$. Investigation and analysis of the impact of Taijiquan traditional health care project on college (university) students' physical and mental health. Youth Sport. 2017: 108-109. doi: 10.3969/j.issn.2095-4581.2017.06.055.

51. Fang LQ. Discussion on teaching "Yi" and "Qi" of Taijiquan in colleges and universities. Inner Mongolia Sports Sci Technol. 2009; 22: 108.

52. Gryffin PA, Chen WC. Implications of t'ai chi for smoking cessation. J Altern Complement Med. 2013; 19: 141-145. 
53. Moore MC. Using meditation in the classroom research. Hispania. 1992; 75: 734-735.

54. Guan R. The significance of Taijiquan being integrated into physical education in colleges and universities. Success. 2010: 273.

55. Liu LF. The value and significance of popularization of Taijiquan in physical education in colleges and universities. Sports World Sch. 2007: 25-26. doi: 10.16730/j.cnki.61-1019/g8.2007.05.011.

56. Si HY. A brief discussion on aesthetic education in Taijiquan teaching. Beauty Times. 2003: 9394. doi: 10.16129/j.cnki.mysdx.2003.03.048.

57. Sun M. Problems in Taijiquan teaching. J Zhengzhou Inst Aeronaut Ind Manag (Soc Sci Ed). 2002; 21: 33-34.

58. Meng S. Research on the practical effectiveness of Taijiquan teaching in colleges and universities. Contemp Sports Technol. 2015; 5: 103-105.

59. Zhang B. Discussion on the role of Taijiquan in Sunshine sports programme in colleges and universities. J Changchun Educ Inst. 2013; 29: 99-100.

60. Cao W, Qi ZH, Li Y. Countermeasures regarding Taijiquan teaching in colleges and universities in Cangzhou city. Blooming Season. 2015; 13: 144.

61. Cheng ML. Values and significance of popularizing Taijiquan in college physical education teaching. J Phys Educ. 2001; 8: 70-71.

62. Su WL. Discussion on the role of Chen Style Taijiquan in the prevention of neurasthenia in university students. Sports World Sch. 2011: 25-27. doi: 10.16730/j.cnki.611019/g8.2011.08.020.

63. Qiu JC. A new approach to the cultivation of college students' interest in practicing Taijiquan. J Fuqing Branch Fujian Normal Univ. 2008; 85: 94-96.

64. Chen XD. An analysis of the value of popularization of Taijiquan among university students. Teacher. 2010; 12: 127-128.

65. Chen QF. The impact of 24-form Taijiquan course on university students' health. Contemp Sports Technol. 2014; 4: 127-128.

66. Huang $X Y, W u X H$, Huang $H$. The necessity and feasibility to open a course in sitting Taijiquan in college sports fitness curriculum. J Phys Educ. 2013; 20: 81-84.

67. Zhang LL. Thoughts on the current situation of Chen style Taijiquan courses in colleges and universities in Henan province. Sports World Sch. 2015: 58-59. doi: 10.16730/j.cnki.611019/g8.2015.10.023.

68. Yang XM, Zhang HL, Niu DS. The preparatory discussion on teaching methods of simplified Taijiquan. J Hengshui Normal Coll. 2003; 5: 76-77.

69. Wang L. A brief discussion on how to cultivate students' creativity in Taijiquan teaching. China Venture Capital. 2012: 187.doi: CNKI:SUN:CYTZ.0.2012-24-170.

70. You JF. Thoughts raised from simplification of Taichi teaching. J Qiannan Univ Nationalities. 2010; 30: 73-77.

71. Yu XH. The "flipped" teaching of Taijiquan. Wushu Stud. 2016; 1: 68-70.

72. Feng YJ. Feasibility analysis of Taijiquan teaching in ordinary colleges and universities. Sci Technol Inf. 2010: J0246. doi: 10.3969/j.issn.1001-9960.2010.35.0186.

73. Liu HZ. Research on the effectiveness of Taijiquan in student psychotherapy. Wushu Sci. 2004; 1: 56-58.

74. Wang XY. Problems in Taijiquan teaching in colleges and universities and measures to improve teaching quality. J Changsha Railway Univ (Soc Sci). 2007; 8: 225-226. 
75. Tian HF. On the present situation of shadow box teaching in universities of Shanxi. J Hubei Sports Sci. 2011; 30: 360-361.

76. Gao QW. Effect of shadowboxing on college students and popularizing measures. J Chongqing Technol Bus Univ (Nat Sci Ed). 2004; 21: 299-301.

77. Zhang RQ. A brief discussion on the significance of Taijiquan courses in vocational colleges. Sport Vision. 2011: 296.

78. Zhu JH, Cheng ML. The function of Tai-Ji-Quan cultural connotation in PE construction teaching. J Nanjing Inst Phys Educ (Soc Sci). 2004; 18: 63-65.

79. Li Y. On the necessity and feasibility of university postgraduates practicing Taijiquan. BOJI(WUSHUKEXUE). 2009; 6: 34-35.

80. Yang XJ. Analysis of Taijiquan practice methods and fitness values in colleges and universities. Blooming Season. 2013: 233. doi: 10.3969/j.issn.1007-5070.2013.12.200.

81. Wang HM. The role of Taijiquan in prevention and treatment of mental illness of university students. Inner Mongolia Sports Sci Technol. 2008; 21: 48-49.

82. Ma L. Thoughts on the popularization of Taijiquan sports from the perspective of university campus cultural construction. Success. 2011: 40.

83. Wang JH. An analysis on the inclusion of sports wellness training courses into physical education elective courses in higher vocational colleges. Chinese Foreign Entrep. 2017: 178. doi: 10.3969/j.issn.1000-8772.2017.06.144.

84. Zheng G, Lan X, Li M, Ling K, Lin H, Chen L, et al. The effectiveness of Tai Chi on the physical and psychological well-being of college students: A study protocol for a randomized controlled trial. Trials. 2014; 15: 129.

85. Scutti S. Tai chi health benefits: 250 million people know what's good for them [Internet]. New York: Medical Daily; 2013. Available from: https://www.medicaldaily.com/tai-chi-healthbenefits-250-million-people-know-whats-good-them-246916.

86. Zhang L, Layne C, Lowder T, Liu J. A review focused on the psychological effectiveness of Tai Chi on different populations. Evid Based Complement Alternat Med. 2012; 2012. doi: 10.1155/2012/678107.

87. Smith SE, Barnes ES, Mason J, Broome J. Place, workplace, and mindful movement. Learning Communities: International Journal of Learning in Social Contexts. 2016; 20: 4-19.

88. Wayne PM, Fuerst M. The Harvard Medical School guide to Tai Chi: 12 weeks to a healthy body, strong heart, and sharp mind. Boston: Shambhala Publications; 2013.

89. Wee KJ. Tàijíquán: True to the art. Auckland, New Zealand: Taijiquan School of Central Equilibrium; 2011.

90. Yang GY, Sabag A, Hao WL, Zhang LN, Jia MX, Dai N, et al. Tai Chi for health and well-being: A bibliometric analysis of published clinical studies between 2010 and 2020. Complement Ther Med. 2021; 60: 102748.

91. Klein PJ, Adams WD. Comprehensive therapeutic benefits of Taiji: A critical review. Am J Phys Med Rehabil. 2004; 83: 735-745.

92. Wilson C, Datta S. Tai chi for the prevention of fractures in a nursing home population: An economic analysis. J Clin Outcomes Manag. 2001; 8: 19-28. 
OBM Integrative and Complementary Medicine 2021; 6(4), doi:10.21926/obm.icm.2104033

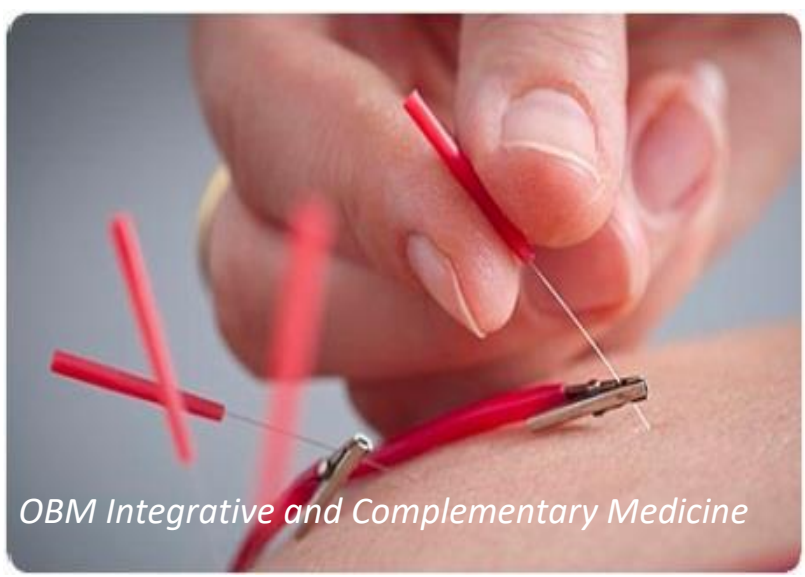

Enjoy $O B M$ Integrative and Complementary Medicine by:

1. Submitting a manuscript

2. Joining in volunteer reviewer bank

3. Joining Editorial Board

4. Guest editing a special issue

For more details, please visit:

http://www.lidsen.com/journals/icm 